\title{
Sistem Informasi Geografis Pemantauan Status Gizi Balita untuk Pemeringkatan Daerah Rawan Gizi dengan Menggunakan Metode Analytical Hierarchy Process pada Kabupaten Lombok Barat
}

\author{
(Geographical Information System for Monitoring the Nutrition Status of Toddlers \\ for Ranking Nutrition-Prone Areas Using the Analytical Hierarchy Process Method \\ in West Lombok Regency)
}

\author{
Sri Endang Anjarwani*, Qori Amalia F, Ida Bagus Ketut Widiartha \\ Program Studi Teknik Informatika, Fakultas Teknik, Universitas \\ Mataram Jl. Majapahit 62, Mataram, Lombok NTB, INDONESIA \\ Email: endang@unram.ac.id, qoryyamaliaa@gmail.com,widi@unram.ac.id
}

\section{"Penulis Korespondensi}

\begin{abstract}
This research was triggered by the increasing number of malnutrition cases in West Lombok Regency that caused the mortality rate of children under five years old is also increasing. This research is aimed to provide the malnutrition status information and other related nutritional information, also to let the citizen send their feedbacks to the Public Health Office and Community Health Clinic. This system was built with waterfall model as its System Development Method and Analytical Hierarchy Process (AHP) method to determine the nutritional areas. This system was tested with blackbox, whitebox and MOS. Whitebox was used to test the Analytical Hierarchy Process and the result was corresponding to the manually done calculation. Meanwhile the testing using blackbox showed that the system has been running well. The testing using MOS showed that the average assessment of public respondents to the system stated strongly agree, agree and fair were $39.04 \%$, $55.24 \%$, and $5.72 \%$ respectively.
\end{abstract}

Key words: Geographical Information System, Toddler's nutritional status, Nutritional Areas, AHP

\section{PENDAHULUAN}

Untuk menghasilkan generasi muda yang berkualitas diperlukan pemantauan terhadap pola makan dan asupan gizi dari usia balita. Upaya yang diberikan bisa dengan berbagai cara supaya tumbuh kembang anak dapat terpantau. Makanan bergizi bisa diperoleh dari sumber makanan sehat dan seimbang sehingga diperoleh gizi yang diperlukan oleh tubuh manusia. Untuk memenuhi kebutuhan gizi balita yang baik tentunya disesuaikan dengan kebutuhan asupan dan makanan yang bergizi sesuai dengan umur dari balita tersebut. Asupan yang bergizi untuk balita sangat diperlukan karena akan berpengaruh terhadap tumbuh kembang otak anak dan perkembangannya pun sangat pesat pada usia ini, jika pemberian nutrisi yang diperoleh tidak seimbang dengan kebutuhan tubuhnya maka dapat berpengaruh terhadap status dari gizi anak itu.

Berdasarkan data dari departemen kesehatan pada tahun 2015 di Nusa Tenggara Barat (NTB) persentase dari balita gizi buruk sebanyak 3.12\% [4], Menurut Dinas Kesehatan Lombok Barat tahun 2015 terdapat kasus gizi buruk berjumlah 49 kasus dan di tahun 2016 meningkat menjadi 98 kasus, dari kasus tersebut yang meninggal dunia [6]. Dari data tersebut terlihat bahwa terdapat banyak kasus gizi buruk di Kabupaten Lombok Barat yang dapat berdampak pada kemungkinan bertambahnya angka kematian pada balita. Hal ini diperlukan adanya pemantauan status gizi balita secara maksimal dan peningkatan kesejahteraan penduduk supaya tidak lagi terjadi kasus gizi buruk pada balita.

Perkembangan Teknologi informasi dan komunikasi melaju dengan pesat, sehingga keberadaan sistem informasi pada Dinas kesehatan Kabupaten Lombok Barat pada saat ini sudah mempunyai aplikasi pemantauan status gizi berbasis sms gateway. Namun aplikasi yang dibangun oleh Dinas Kesehatan Lombok Barat berhenti digunakan karena terlalu mahalnya biaya operasional dan aplikasi tersebut tidak dapat memetakan daerah berdasarkan status gizinya.

Untuk itu penulis mencoba untuk membuat suatu sistem informasi geografis yang dapat memantau status gizi balita di Kabupaten Lombok Barat berbasis website yang dapat memetakan dan memberikan informasi status gizi balita, dan dapat memberikan informasi mengenai daerah rawan gizi agar dapat dilakukan penanganan, di mana daerahdaerah rawan tersebut. Metode yang digunakan adalah metode Analytic Hierarcy Process (AHP) dengan mempertimbangkan setiap penentuan kriteria yang dibutuhkan. Metode ini digunakan karena dapat membantu dalam pemecahan suatu masalah salah satunya dalam penanganan daerah rawan. Dengan begitu diharapkan 
sistem ini dapat membantu pemerintah dan masyarakat memantau status gizi balita dan memudahkan petugas di setiap puskesmas untuk mengolah dan menganalisis data gizi di Kabupaten Lombok barat. Bukan hanya itu terdapat fitur pengaduan, di mana fitur tersebut berguna untuk memudahkan masyarakat memberikan pengaduan, pesan atau saran kepada pemerintah mengenai pelayan status gizi.

\section{TINJAUAN PUSTAKA}

Penelitian dengan judul "Sistem Informasi Geografis (SIG) Pemantauan Balita Gizi Buruk di Surabaya". Penelitian tersebut dilakukan untuk membangun aplikasi yang apabila di implementasikan di Kota Surabaya dapat membantu pemerintah dalam menangani kasus gizi buruk yang memiliki cukup banyak kasus gizi buruk terutama dari sisi proses pengolahan data, analisis permasalahan, dan pemetaan daerah rawan gizi buruk. Dengan demikian dengan adanya aplikasi ini diharapkan kasus gizi buruk di Kota Surabaya bisa berkurang dan cepat diatasi. Dalam pembuatan aplikasi ini peneliti menggunakan teknologi Map Server dan Mysql Spasial dikembangkan ke dalam web. Pengembangan arsitektur sistem mengikuti arsitektur client-server, dan menggunakan pmapper untuk menampilkan peta [3].

Pada penelitian yang lain terkait dengan Aplikasi Sistem Informasi Geografis Pada Pemantauan Status Gizi Balita di Dinas Kesehatan Kabupaten Sukoharjo". Penelitian ini dibahas tentang aplikasi pemantauan gizi berbasis SIG yang digunakan untuk membantu dan mendukung kegiatan PSG menjadi lebih baik terutama dari sisi proses pengolahan data, analisis data, penyajian data dan pelaporan lebih mudah, lengkap, cepat, tepat waktu dan sesuai dengan kondisi setiap wilayah yang ada di Kabupaten Sukoharjo. Dengan demikian pengambilan keputusan mengenai kebijakan penanggulangan gizi buruk dan perbaikan gizi menjadi lebih cepat, mudah dan tepat sasaran. Dalam pembuatan aplikasinya, peneliti menggunakan bahasa pemrograman PHP sebagai tools pengembangan aplikasi, SQL untuk pembuatan database aplikasi dan map server digunakan sebagai pembuatan peta aplikasi [1].

Penelitian yang lain yaitu "Pemanfaatan Sistem Informasi Geografis Dengan Metode Analytical Hierarchy Process (AHP) Untuk Prediksi Daerah Rawan Banjir di Kota Semarang". Dengan penelitian ini diharapkan dapat menerapkan sistem informasi yang dibuat sebagai pengawasan bencana guna meminimalisir dampak dari bencana di Kota Semarang. Sistem Informasi yang dihasilkan dapat digunakan untuk menyajikan informasi tentang pemetaan prediksi daerah rawan banjir Kota Semarang, sehingga informasi daerah banjir dan indikator banjirnya dapat digunakan oleh dinas pemerintah dan masyarakat untuk mengantisipasi dampak bencana banjir. Informasi spasial direpresentasikan dalam bentuk peta dari hasil perhitungan scoring dan pembobotan pada setiap atribut dan informasi spasial di dalam Sistem Informasi Geografis menggunakan metode AHP dan pengolahan data dilakukan dengan cara digital dengan ArcGIS.[2]
Berikutnya penelitian pada pengujian Sistem Informasi Geografis Pemetaan Persebaran Alumni bertujuan untuk menemukan kesalahan fungsi pada program, dari hasil pengujian black box diperoleh hasil bahwa output diharapkan sesuai dengan output hasil eksekusi. Pengujian dilakukan dengan cara pengguna melakukan entry data atau masukan terhadap sistem yang sudah berjalan dan mengamati hasil output dari hasil pengujian [7].

\section{METODE USULAN}

Metode yang digunakan untuk pengembangan sistem pada penelitian ini adalah metode waterfall yang tahapannya seperti yang terlihat pada Gambar 1. Pada Gambar 1 dapat dilihat bahwa pengembangan sistem dimulai dengan pendefinisian dan menganalisis kebutuhan dari sistem yang akan dibangun. Setelah kebutuhan sistem telah dianalisis akan dilanjutkan dengan perancangan sistem yakni merancang usecase diagram dan entity relationship diagram (ERD) dan kemudian dilanjutkan dengan tahapan coding dan implementasi sistem. Pada tahapan pengujian, akan digunakan metode blackbox, whitebox dan MOS (Mean Opinion Score) untuk menguji apakah sistem telah berjalan sesuai dengan harapan.

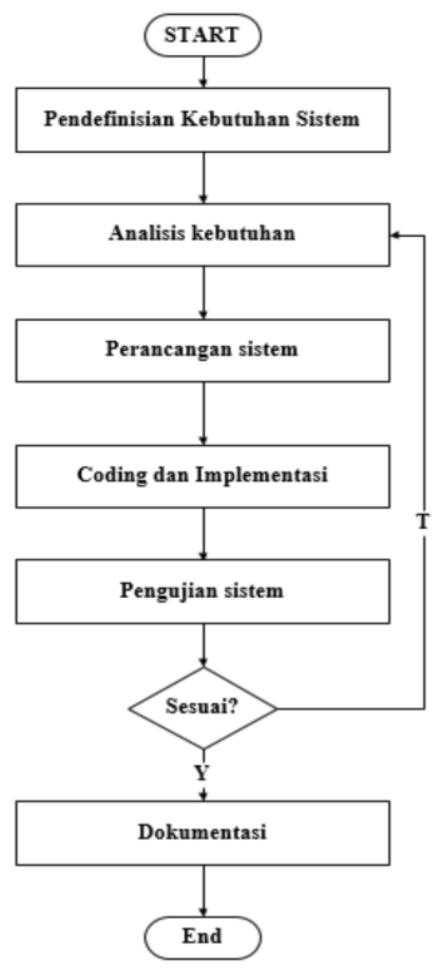

Gambar 1. Flowchart pembuatan sistem

Untuk pengambilan keputusan mengenai daerah rawan gizi pada sistem ini menggunakan metode Analytical Hierarchy Process (AHP) yaitu dengan menjumlahkan nilai pembobotan dari kriteria yang sudah ditetapkan sebelumnya. Seperti kriteria masalah gizi, fasilitas kesehatan dan tingkat keluarga miskin. Alur kerja metode AHP adalah seperti yang ditunjukkan pada Gambar 2. 


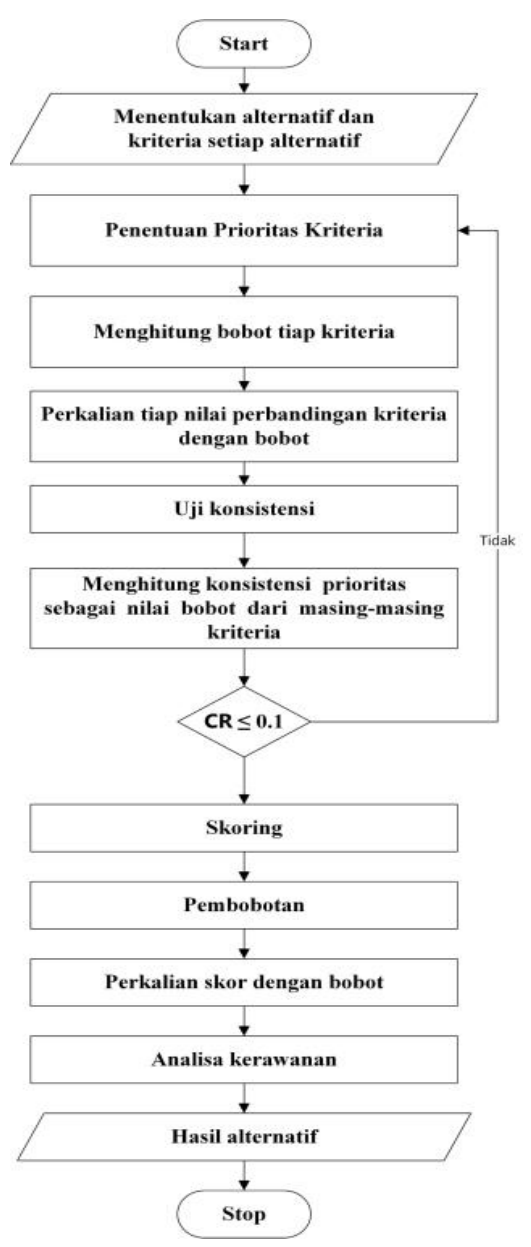

Gambar 2. Flowchart AHP

Berikut ini adalah deskripsi dari masing-masing kriteria:

1. Kriteria Masalah Gizi

Berikut ini pada Tabel I adalah klasifikasi jumlah masalah gizi [4].

TABEL I. KLASIFIKASI JUMLAH MASALAH GIZI

\begin{tabular}{|c|c|c|c|c|c|}
\hline No & $\begin{array}{c}\text { Jumlah masalah gizi } \\
(\mathrm{G})\end{array}$ & Klasifikasi & $\begin{array}{c}\text { Warna } \\
\text { Peta }\end{array}$ & Skor & Bobot \\
\hline 1 & $\mathrm{G}<10 \%$ & Baik & Hijau & 1 & \multirow{2}{*}{0,702838828} \\
\hline 2 & $10 \% \geq \mathrm{G}<20 \%$ & Kurang & Kuning & 2 & \\
\cline { 1 - 4 } 3 & $20 \% \geq \mathrm{G}<30 \%$ & Buruk & Merah & \multirow{2}{*}{3} & \\
\cline { 1 - 4 } 4 & $\mathrm{G} \geq 30$ & Sangat Buruk & Hitam & \multicolumn{1}{|c|}{4} & \\
\hline
\end{tabular}

2. Kriteria Fasilitas Kesehatan

Berikut ini pada Tabel II adalah klasifikasi jumlah fasilitas kesehatan [5].

TABEL II. KLASIFIKASI JUMLAH FASKES

\begin{tabular}{|c|c|c|c|c|c|}
\hline No & $\begin{array}{c}\text { Jumlah Fasilitas } \\
\text { Keskhatan (F) }\end{array}$ & Klasifikasi & Warna peta & Skor & Bobot \\
\hline 1 & F $=0$ & Tidak ada & Kuning & 2 & 0,1149267 \\
\hline 2 & F $\geq 1$ & Ada & Hijau & 1 & 4 \\
\hline
\end{tabular}

3. Kriteria Keluarga Miskin

Berikut ini pada Tabel III adalah klasifikasi jumlah keluarga miskin [6].

TABEL III. KLASIFIKASI JUMLAH GAKIN

\begin{tabular}{|c|c|c|c|c|c|}
\hline No & $\begin{array}{c}\text { Rata-rata jumlah } \\
\text { keluarga miskin (K) }\end{array}$ & Klasifikasi & $\begin{array}{c}\text { Warna } \\
\text { peta }\end{array}$ & Skor & Bobot \\
\hline 1 & $\mathrm{~K}<500$ & Sedikit & Hijau & 1 & \multirow{4}{*}{0,182234432} \\
\hline 2 & $500 \geq \mathrm{K}<5000$ & Sedang & Kuning & 2 & \\
\hline 3 & $5000 \geq K<10000$ & Banyak & Merah & 3 & \\
\hline 4 & $K \geq 10000$ & $\begin{array}{l}\text { Sangat } \\
\text { Banyak }\end{array}$ & Hitam & 4 & \\
\hline
\end{tabular}

4. Prioritas Kriteria

Prioritas kriteria merupakan gabungan dari skor semua kriteria yang telah ditentukan. Di mana prioritas kriteria ini digunakan untuk menentukan penanganan yang akan dilakukan terlebih dahulu pada daerah rawan gizi. Berikut ini pada Tabel IV adalah klasifikasi prioritas kriteria.

TABEL IV. KLASIFIKASI PRIORITAS KRITERIA

\begin{tabular}{|c|c|c|c|c|}
\hline No & Jumlah skor & Klasifikasi & Warna peta & Skor \\
\hline 1 & $\mathrm{~J}<3,1$ & Prioritas pertama & Hitam & 4 \\
\hline 2 & $2,4 \geq \mathrm{J}<3,1$ & Prioritas kedua & Merah & 3 \\
\hline 3 & $1,7 \geq \mathrm{j}<2,4$ & Prioritas ketiga & Kuning & 2 \\
\hline 4 & $\mathrm{~J}<1,7$ & Prioritas keempat & Hijau & 1 \\
\hline
\end{tabular}

Pada perancangan sistem informasi, untuk mengetahui gambaran dari kelakuan (behavior) sistem yang akan dibuat diperlukan suatu proses yaitu membuat diagram usecase yang berfungsi untuk mendefinisikan atau menggambarkan hubungan sebuah sistem dengan penggunanya. Berikut ini adalah rancangan usecase yang nampak pada Gambar 3. Dari rancangan usecase pada Gambar 3, dapat dilihat bahwa terdapat 3 aktor yang dapat menggunakan sistem yakni Masyarakat, Petugas Puskesman dan Petugas Dikes. Masyarakat akan mendapatkan berbagai informasi seperti informasi daerah rawan gizi, lokasi fasilitas kesehatan, tingkat keluarga miskin dan informasi daerah masalah gizi. Selain itu, masyarakat juga dapat membuat pesan pengaduan yang nantinya dapat ditindaklanjuti oleh Petugas Dikes. Petugas Puskesmas akan dapat mengelola data posyandu dan data balita. Sedangkan, untuk Petugas Dikes akan mengelola data status gizi dan data keluarga miskin. Petugas Dikes juga dapat dengan mudah untuk melihat rekap laporan puskesmas dan laporan lainnya perkabupaten.

Tahap selanjutnya yaitu membuat rancangan database, yaitu merupakan tempat yang akan digunakan untuk penyimpanan file secara keseluruhan yang diperlukan dalam sistem, sehingga data dapat terintegrasi satu dengan yang lainnya. Untuk rancangan database yang digunakan pada sistem ini adalah seperti terlihat pada Gambar 4. Pada Gambar 4 dapat dilihat bahwa terdapat 8 entitas dalam rancangan ERD yakni entitas Admin, Pesan, Balita, Faskes, Desa, Kecamatan, Timbang dan entitas Gakin. 


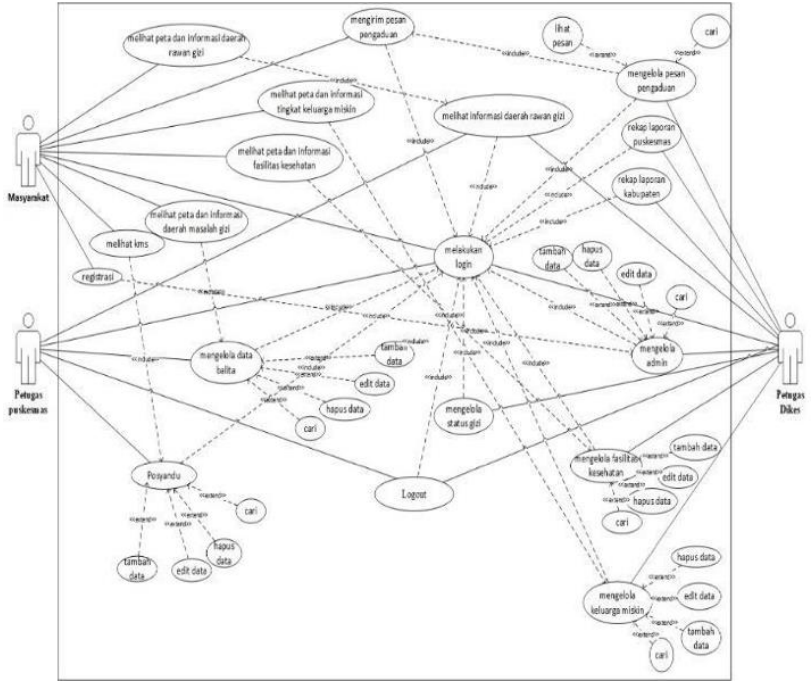

Gambar 3. Rancangan usecase

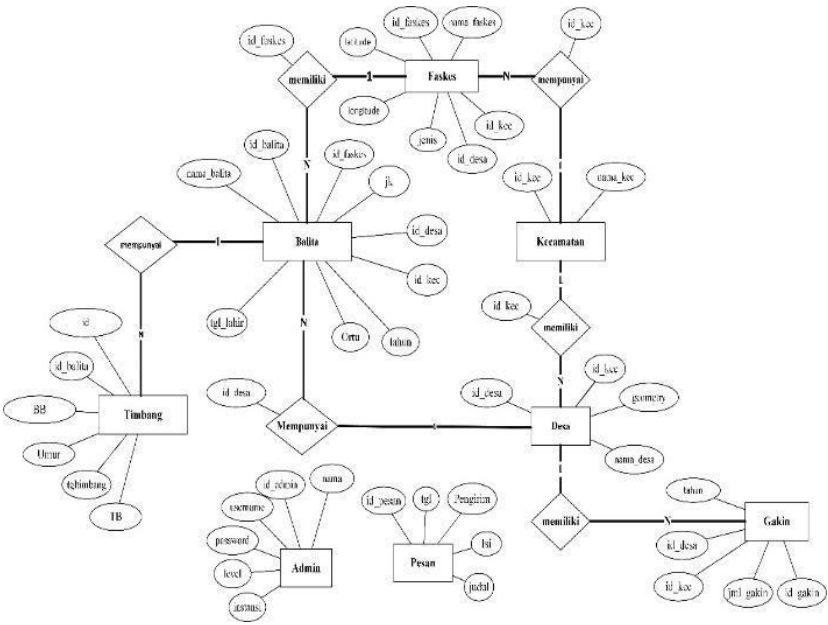

Gambar 4. Rancangan database

\section{HASIL DAN IMPLEMENTASI}

\section{A. Implementasi Antar muka}

Hasil dari sistem yang dikembangkan yang nantinya dapat diimplemetasi kepada admin Dinas Kesehatan, admin petugas puskesmas dan masyarakat berupa implementasi sistem dengan beberapa tampilan interface berdasarkan pengguna sistem. Berikut hasil dari implementasi interface atau tampilan sistem dapat dilihat pada Gambar 5 sampai dengan Gambar 13.

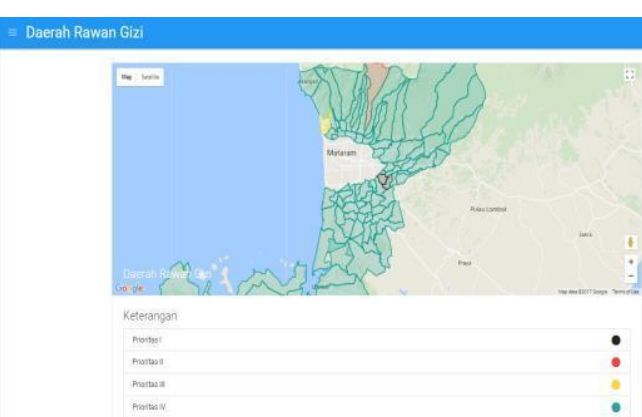

Gambar 5. Implementasi peta daerah rawan gizi

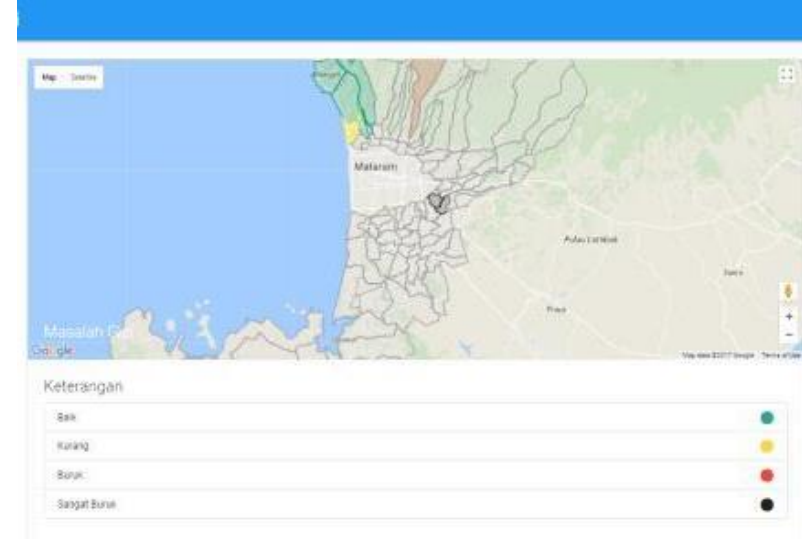

Gambar 6. Implementasi peta masalah gizi

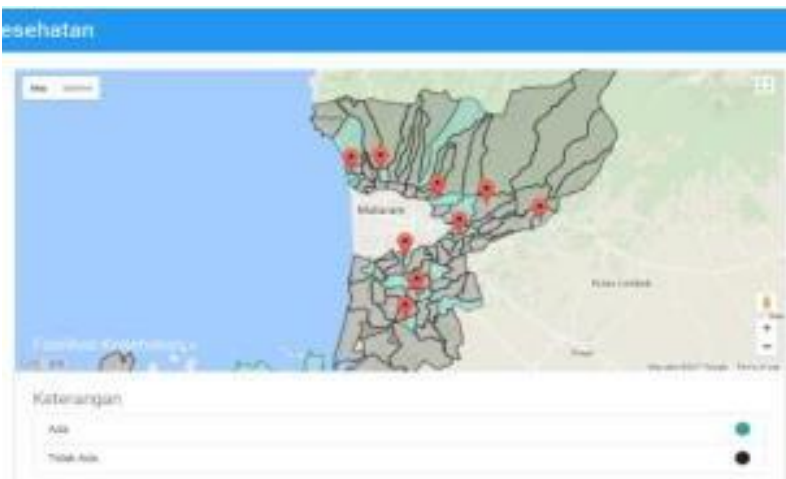

Gambar 7. Implementasi peta faskes

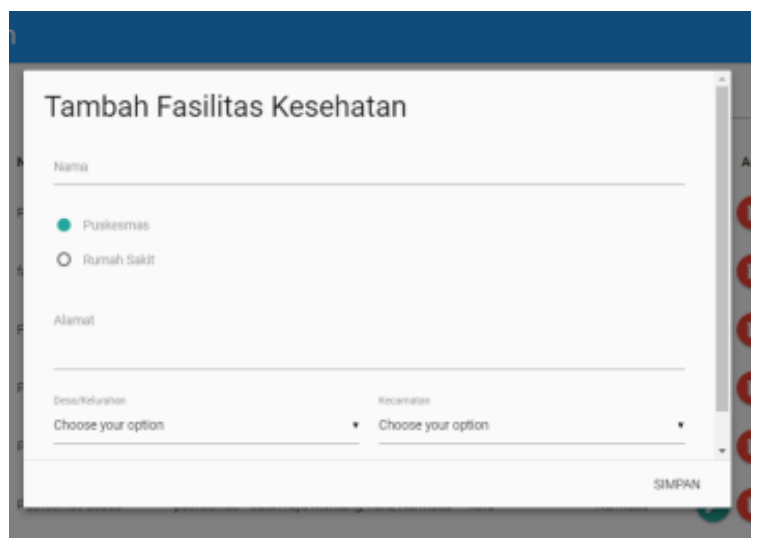

Gambar 8. Implementasi Tambah Faskes

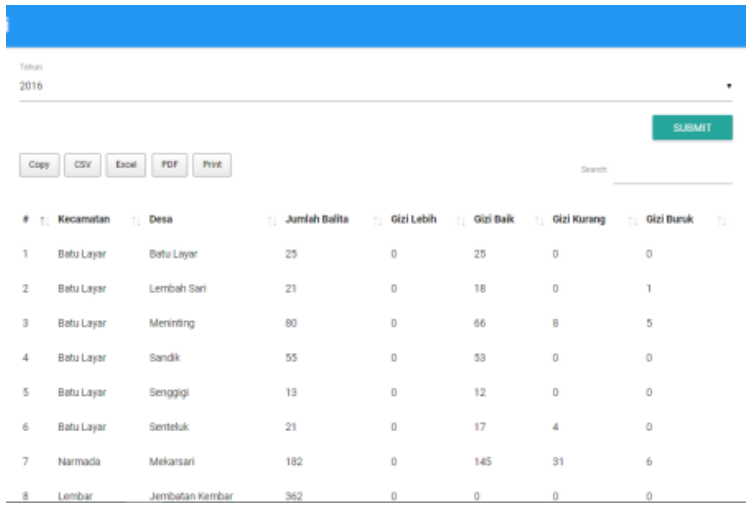

Gambar 9 Implementasi Status gizi 


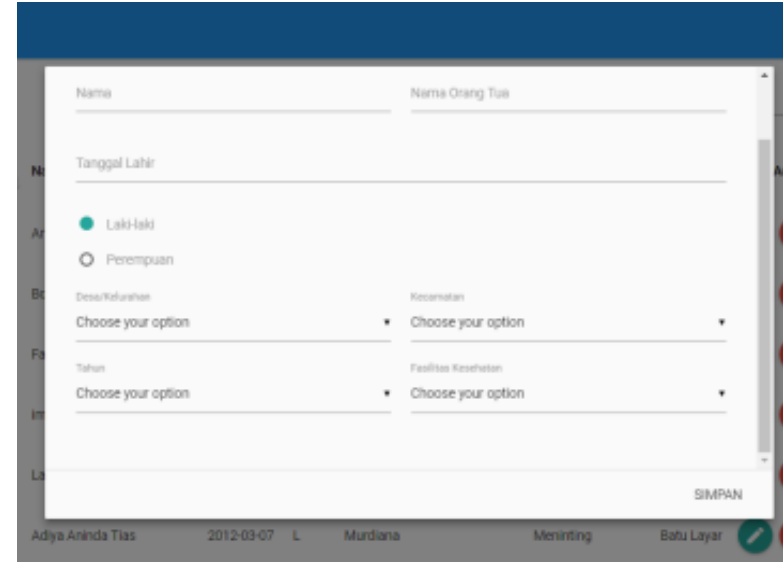

Gambar 10. Implementasi Tambah balita

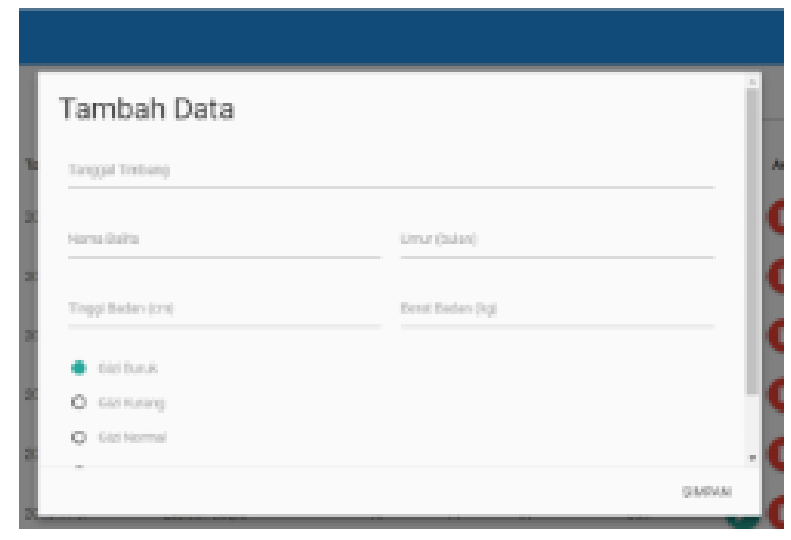

Gambar 11. Implementasi posyandu

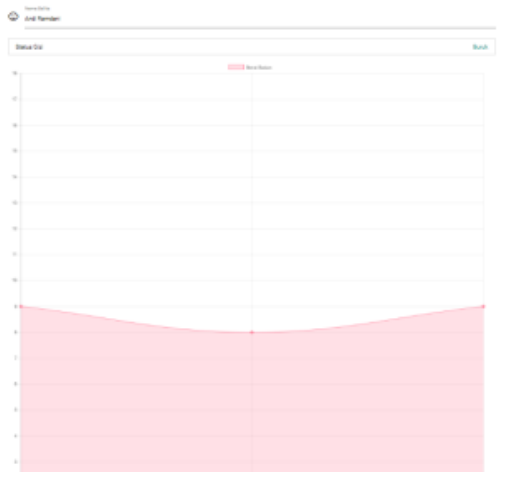

Gambar 12. Implementasi KMS

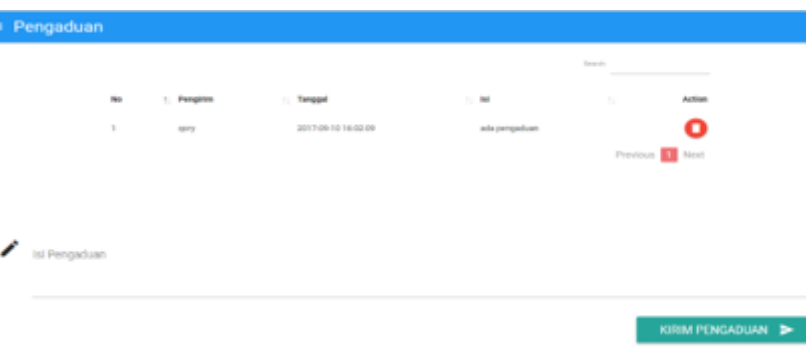

Gambar 13. Implementasi Pengaduan

\section{B. Pengujian Sistem}

1. Pengujian White Box
Pengujian dengan white box ini akan digunakan untuk menguji kesesuaian rumus perhitungan yang ada pada metode AHP untuk penentuan daerah rawan masalah gizi. Dengan hasil perhitungan yang secara manual seperti terlihat pada Tabel V.

TABEL V. HASIL ALTERNATIF

\begin{tabular}{|c|l|c|c|}
\hline No & Nama desa & Jumlah skor & Warna peta \\
\hline 1 & Meninting & 1,88507326 & Kuning \\
\hline 2 & Batu layer & 1,479395604 & Hijau \\
\hline 3 & Lembah sari & 1,297161172 & Hijau \\
\hline
\end{tabular}

Dan hasil pada program adalah seperti yang ditunjukkan pada Gambar 14.

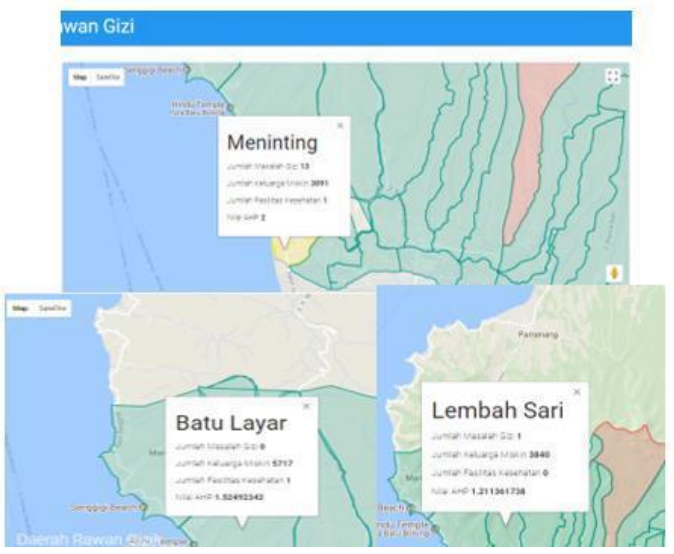

Gambar 14. Hasil perhitungan pada program

\section{Pengujian Black Box}

Pengujian dengan metode black box adalah suatu metode digunakan untuk menguji fungsi- fungsi yang terdapat pada sistem. Dari hasil tersebut dapat diketahui apakah setiap fitur dapat beroperasi sesuai dengan yang diharapkan atau belum sesuai. Hasil yang didapat dengan blackbox pada sistem menunjukkan bahwa semua fungsi pada sistem dapat berfungsi dan beroperasi dengan baik sesuai dengan rencana.

\section{Pengujian Kuisioner}

Pengujian menggunakan kuisioner membutuhkan responden untuk mencoba mengoperasikan sistem, kemudian kuisioner yang berupa pertanyaan diberikan untuk dijawab sesuai dengan pertanyaan yang tersedia guna mengetahui hasil dari sistem yang dioperasikan. Pengujian menggunakan kuisinoner bertujuan untuk melihat usabilitas dari sistem dari sudut pandang pengguna. Sistem diuji pada server side, program dijalankan pada server localhost secara stand alone.

Pelaksanaan pengujian dengan melibatkan berjumlah 30 orang sebagai responden yakni 4 (empat) orang berasal dari Dinas Kesehatan Kabupaten Lombok Barat dan 5 (lima) orang dari fasilitas kesehatan sebagai admin yang dapat mengelola sistem. Sedangkan 21 orang dari masyarakat sebagai responden yang mencoba setiap 
tampilan pada sistem yang digunakan sebagai hasil pengujian terhadap sistem.

Kuisioner pengujian untuk pengguna umum atau masyarakat Kabupaten Lombok Barat terdiri dari 10 pertanyaan, antara lain:

1. Perpaduan warna website nyaman dipandang mata

2. Rancangan dari tampilan mudah dimengerti

3. Adanya navigasi yang disajikan dapat membantu penelusuran.

4. Sistem dapat memberikan informasi masalah gizi balita di setiap desa dalam bentuk peta

5. Sistem dapat menampilkan informasi daerah yang memiliki rawan masalah gizi balita di setiap desa dalam bentuk peta

6. Sistem dapat menampilkan peta lokasi puskesmas dan rumah sakit di kabupaten Lombok Barat

7. Sistem dapat memberikan informasi jumlah keluarga miskin di setiap desa dalam bentuk peta

8. Sistem dapat memberikan informasi perkembangan berat badan balita

9. Untuk pertanyaan yang nomor 9 ini sama dengan pertanyaan nomor 10 kuisioner pada kuisioner admin.

10. Sistem bisa dijadikan sebagai alat untuk membantu masyarakat menyampaikan kritik dan saran

Kuisioner pengujian untuk admin petugas puskesmas dan admin Dinas Kesehatan kabupaten Lombok Barat terdiri dari 10 pertanyaan, yaitu :

1. Perpaduan warna pada website terasa nyaman dioperasikan

2. Rancangan tampilan yang dibuat mudah dipahami?

3. Navigasi yang disajikan memberikan kemudahan dalam penelusuran

4. Data yang ada pada sistem ini sesuai dengan data yang dibutuhkan

5. Sistem dapat memberikan informasi masalah gizi balita di setiap desa dalam bentuk peta

6. Sistem dapat memberikan informasi daerah rawan masalah gizi balita di setiap desa dalam bentuk peta

7. Sistem dapat menampilkan peta lokasi puskesmas dan rumah sakit di kabupaten Lombok Barat

8. Sistem dapat memberikan informasi jumlah keluarga miskin di setiap desa dalam bentuk peta

9. Sistem dapat menerima pesan dari user atau masyarakat ke Dinas Kesehatan Kabupaten Lombok Barat

10. Sistem dapat digunakan sebagai alat bantu untuk memantau status gizi balita di Kabupaten Lombok Barat

Hasil dari jawaban kuisioner responden dikelompokkan menjadi dua yaitu masyarakat dan admin Dinas Kesehatan dan petugas puskesmas kemudian akan menghitung dan mengambil kesimpulan sesuai dengan pengujian yang dilakukan. Dari pertanyaan tersebut, responden akan menjawab dengan memberikan nilai yang sudah ditentukan, yaitu :
1. menyatakan Sangat tidak setuju

2. menyatakan Tidak setuju.

3. menyatakan Cukup.

4. menyatakan Setuju.

5. menyatakan Sangat setuju

Tahapan berikutnya yang dilakukan adalah melakukan perhitungan persentase dari hasil jawaban dari responden pada setiap pernyataan. Untuk menghitung persentase nilai menggunakan rumus sesuai dengan Persamaan (1):

$$
\text { Persentase }=(\mathrm{J} / \mathrm{N}) * 100 \%
$$

Keterangan:

$\mathbf{J}=$ total nilai jawaban pertanyaan yang diberikan responden.

$\mathrm{N}=$ banyaknya responden.

Kemudian untuk memperoleh rata-rata persentase dari setiap poin jawaban, dilakukan perhitungan dengan menerapkan rumus sesuai dengan Persamaan (2):

Rata-rata $=($ Persentase ke $-1+\ldots+$ Persentase ke $-n) / n$

Hasil persentase terhadap jawaban kuesioner responden yaitu berupa jawaban sangat tidak setuju, tidak setuju, cukup, setuju dan sangat setuju nilai dari setiap jawaban tersebut selanjutnya dijumlahkan secara keseluruhan untuk didefinisikan sebagai nilai rata-rata. Untuk hasil perhitungan jawaban dari masing-masing responden untuk setiap pertanyaan pada kuesioner menggunakan cara perhitungan Persamaan (1) dan Persamaan (2) yakni seperti yang terlihat pada Tabel VI dan VII.

Pada Tabel VI dapat terlihat bahwa hasil rata-rata pengujian kuisioner untuk responden masyarakat umum terhadap sistem menyatakan sangat setuju dan setuju dengan persentase masing-masing $39.04 \%$ dan $55.24 \%$ sedangkan $5.72 \%$ menyatakan cukup. Pada Tabel VII dapat terlihat bahwa hasil rata-rata pengujian kuisioner untuk responden Dinas Kesehatan Kabupaten Lombok barat dan petugas puskesmas terhadap sistem menyatakan sangat setuju dan setuju dengan persentase masing-masing $4.44 \%$ dan $73.34 \%$ sedangkan $22.22 \%$ menyatakan cukup.

TABEL VI. HASIL PENGUJIAN KUESIONER UNTUK RESPONDEN MASYARAKAT

\begin{tabular}{|c|c|c|c|c|c|}
\hline \multirow{2}{*}{ Pertanyaan } & \multicolumn{5}{|c|}{ Persentase } \\
\cline { 2 - 6 } & $\begin{array}{c}\text { Sangat } \\
\text { Setuju }\end{array}$ & Setuju & Cukup & $\begin{array}{c}\text { Kurang } \\
\text { Setuju }\end{array}$ & $\begin{array}{c}\text { Tidak } \\
\text { Setuju }\end{array}$ \\
\hline 1 & $28.57 \%$ & $71.43 \%$ & $0 \%$ & $0 \%$ & $0 \%$ \\
\hline 2 & $38.09 \%$ & $52.39 \%$ & $9.53 \%$ & $0 \%$ & $0 \%$ \\
\hline 3 & $28.57 \%$ & $66.67 \%$ & $4,76 \%$ & $0 \%$ & $0 \%$ \\
\hline 4 & $57.14 \%$ & $33.33 \%$ & $9.53 \%$ & $0 \%$ & $0 \%$ \\
\hline 5 & $42.86 \%$ & $57.14 \%$ & $0 \%$ & $0 \%$ & $0 \%$ \\
\hline 6 & $57.14 \%$ & $38.09 \%$ & $4,77 \%$ & $0 \%$ & $0 \%$ \\
\hline 7 & $38.09 \%$ & $61.91 \%$ & $0 \%$ & $0 \%$ & $0 \%$ \\
\hline 8 & $38.09 \%$ & $57.14 \%$ & $4.77 \%$ & $0 \%$ & $0 \%$ \\
\hline 9 & $38.09 \%$ & $52.38 \%$ & $9.53 \%$ & $0 \%$ & $0 \%$ \\
\hline 10 & $23.81 \%$ & $61.91 \%$ & $14.28 \%$ & $0 \%$ & $0 \%$ \\
\hline
\end{tabular}


TABEL VII. Hasil PENGuJian Kuesioner untuk Admin Dinas KeSEHATAN DAN PETUGas PUSKeSMAS

\begin{tabular}{|c|c|c|c|c|c|}
\hline \multirow{2}{*}{ Pertanyaan } & \multicolumn{5}{|c|}{ Persentase } \\
\cline { 2 - 6 } & $\begin{array}{l}\text { Sangat } \\
\text { Setuju }\end{array}$ & Setuju & Cukup & $\begin{array}{l}\text { Kurang } \\
\text { Setuju }\end{array}$ & $\begin{array}{l}\text { Tidak } \\
\text { Setuju }\end{array}$ \\
\hline 1 & $0 \%$ & $100 \%$ & $0 \%$ & $0 \%$ & $0 \%$ \\
\hline 2 & $0 \%$ & $66.67 \%$ & $33.33 \%$ & $0 \%$ & $0 \%$ \\
\hline 3 & $11.11 \%$ & $55.56 \%$ & $33.33 \%$ & $0 \%$ & $0 \%$ \\
\hline 4 & $0 \%$ & $66.67 \%$ & $33.33 \%$ & $0 \%$ & $0 \%$ \\
\hline 5 & $0 \%$ & $88.89 \%$ & $11.11 \%$ & $0 \%$ & $0 \%$ \\
\hline 6 & $0 \%$ & $77.78 \%$ & $22.22 \%$ & $0 \%$ & $0 \%$ \\
\hline 7 & $0 \%$ & $100 \%$ & $0 \%$ & $0 \%$ & $0 \%$ \\
\hline 8 & $0 \%$ & $77.78 \%$ & $22.22 \%$ & $0 \%$ & $0 \%$ \\
\hline 9 & $11.11 \%$ & $66.67 \%$ & $22.22 \%$ & $0 \%$ & $0 \%$ \\
\hline 10 & $22.22 \%$ & $33.33 \%$ & $44.44 \%$ & $0 \%$ & $0 \%$ \\
\hline
\end{tabular}

Berdasarkan persentase tiap jawaban, maka dapat disimpulkan persentase rata-rata untuk setiap kategori kuesioner, adalah seperti yang ditunjukkan pada Gambar 15 dan Gambar 16

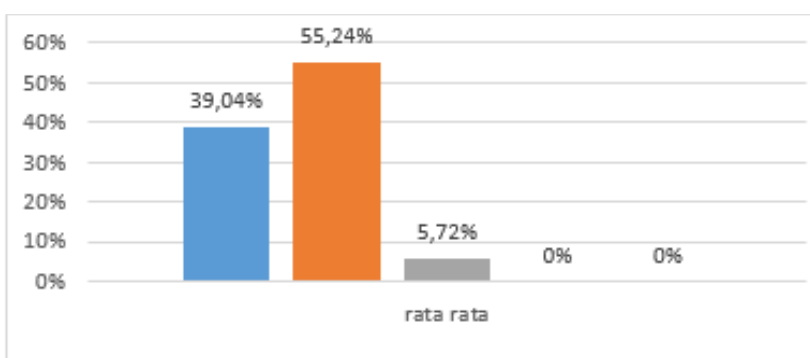

| sangat setuju | setuju || cukup || tidak setuju | sangat tidak setuju

Gambar 15. Grafik rata-rata jawaban responden masyarakat

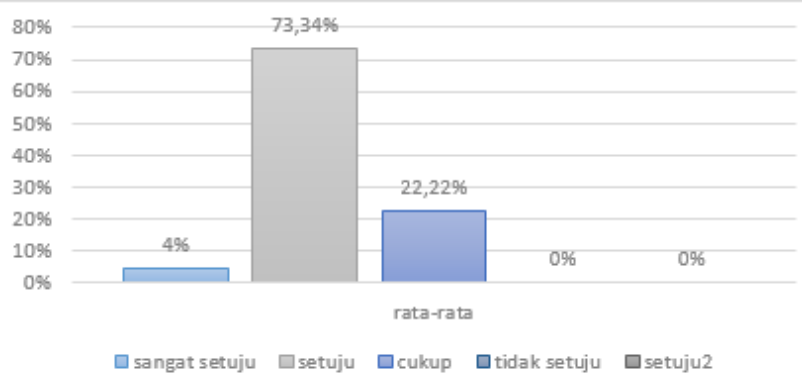

Gambar 16. Grafik jawaban responden admin Dinas Kesehatan dan petugas puskesmas

\section{KESIMPULAN DAN SARAN}

\section{A. Kesimpulan}

Berdasarkan hasil pembahasan dan pengujian yang dilakukan pada pembangunan sistem ini, maka dapat ditarik kesimpulan sebagai berikut:

1. Penerapan metode Analytical Hierarchy Process (AHP) dalam sistem dapat membantu dalam penentuan daerah rawan gizi di Kabupaten Lombok barat.
2. Sistem ini memanfaatkan google maps API untuk menampilkan peta daerah rawan gizi, masalah gizi, fasilitas kesehatan dan keluarga miskin.

3. Hasil pengujian dengan menggunakan black box diperoleh hasil bahwa semua fitur dalam sistem telah beroperasi sesuai dengan rancangan yang dibuat.

4. Untuk Pengujian dengan white box menyatakan bahwa dengan rumus tersebut menghasilkan nilai yang sesuai dengan proses rancangan pada penerapan metode AHP sehingga berfungsi sebagaimana mestinya dengan mendapatkan hasil prioritas penanganan daerah rawan gizi di Kabupaten Lombok Barat.

5. Dari hasil pengujian MOS menunjukkan bahwa ratarata penilaian responden masyarakat umum terhadap sistem menyatakan sangat setuju dan setuju dengan persentase masing-masing $39.04 \%$ dan $55.24 \%$ sedangkan $5.72 \%$ menyatakan cukup. Sedangkan rata-rata penilaian responden Dinas Kesehatan Kabupaten Lombok barat dan petugas puskesmas terhadap sistem menyatakan sangat setuju dan setuju dengan persentase masing-masing $4.44 \%$ dan $73.34 \%$ sedangkan $22.22 \%$ menyatakan cukup. Sehingga dapat disimpulkan bahwa sistem ini layak untuk digunakan.

\section{B. Saran}

Untuk lebih lengkapnya dari sistem yang dihasilkan ini maka penulis menyampaikan saran untuk ke depannya dapat dilakukan perbaikan dan pengembangan terhadap aplikasi yang telah dibuat, maka disarankan hal - hal sebagai berikut:

1. Untuk penelitian selanjutnya, peneliti dapat mengintegrasikan sistem ini dengan sistem yang sudah tersedia di dinas kesehatan Kabupaten Lombok barat.

2. Untuk penelitian selanjutnya dapat menambahkan pemetaan masalah gizi balita berdasarkan $\mathrm{BB} / \mathrm{U}$ dan $\mathrm{PB} / \mathrm{U}$ karena pada penelitian yang sekarang hanya menampilkan peta berdasarkan BB/TB.

3. Fasilitas kesehatan dapat ditambahkan dengan fasilitas kesehatan yang lain seperti puskesmas pembantu.

\section{DAFTAR PUSTAKA}

[1] Multazimah., Handaga, B., Sigit, A.A., 2006, Aplikasi Sistem Informasi Geografis Pada Pemantauan Status Gizi Balita di Dinas Kesehatan Kabupaten Sukoharjo Universitas Muhammadiyah Surakarta, Jawa Tengah.

[2] Rahmawati, U.D., Basofi, A., Achsan, A.S., 2002, Sistem Informasi Geografis (Sig) Pemantauan Balita Penderita Gizi Buruk Di Surabaya, Institut Teknologi Sepuluh Nopember, Surabaya.

[3] Imanda A.R., Andono P.N., 2014, Pemanfaatan Sistem Informasi Geografis Dengan Metode Analytical Hierarchy Process (Ahp) Untuk Prediksi Daerah Rawan Banjir Di 
Kota Semarang, Universitas Dian Nuswantoro Semarang, Jawa Tengah.

[4] Dinas Kesehatan Provinsi Nusa Tenggara Barat, 2015, Laporan PSG Dinas Kesehatan Provinsi NTB, Mataram.

[5] Dinas Kesehatan Kabupaten Lombok Barat, 2016, Profil Kesehatan Kabupaten Lombok Barat Tahun 2016, Kabupaten Lombok Barat.
[6] Dinas Sosial, Tenaga Kerja, dan Transmigrasi Kabupaten Lombok Barat, 2016, Data jumlah keluarga miskin, Kabupaten Lombok Barat.

[7] Iskandar, Adi Panca Saputra, I Kadek Dwi Gandika Supartha, 2019, Sistem Informasi Geografis Pemetaan Sebaran Alumni Pada STMIK STIKOM Indonesia, JCOSINE, Vol. 3, No. 2 